\title{
Medical Personnel in Post-Apartheid South Africa: The Nexus between Political Change and Migration
}

\section{Anand Singh}

\begin{abstract}
This paper is based on research that provides an overview of the factors that encourage international migration among medical workers from Sub-Saharan Africa. Through a brief insight into Sub-Saharan Africa and an in-depth view of working conditions in one of South Africa's city's hospitals (Durban) we are able to appreciate what spurs on the urge to migrate northwards. The choice of these two categories rests with how the dynamics of transformation and equity policies are manifesting more than two decades after the country's first general election. In viewing their qualifications as an enabling factor in their mobility, the discussion here locates the actual experiences of South African medical personnel within the broader framework of working and political conditions in the African continent. The assertion in this paper is that while the choice for international relocation is both professional and personal, they actually emerge out of a plethora of disablements. In South Africa it is especially through endemic violence and affirmative action (push factors), viewed here as a re-racialisation of post-apartheid South Africa. Political transformation after April 1994 has led from exuberant euphoria to utter despair in service deliveries. The health service has not been spared by the complacencies of bureaucratic inertia, selective appointments and reverse racism. It is against the backdrop of such conditions that the perceived positive social and political conditions in developed countries have become major sources of attraction for medical personnel from South Africa. Through the use of interviews and observations, this paper reveals that the current working situation for doctors in South Africa is more retrogressive than progressive.
\end{abstract}

Keywords: medical personnel, political change, South Africa, migration 


\section{Anand Singh}

\section{Introduction}

The purpose of this paper is threefold: To view the increasing exodus of medical workers from South Africa as part of a global trend to countries with better provisioned facilities and opportunities for personal and familial upliftment; to briefly highlight social and professional issues such as working conditions, factors that inhibit upward mobility and asphyxiating socieconomic conditions that instigate migration from South Africa; and to specifically focus upon the conditions that lead to the flight of medical workers from South Africa. The concept 'medical workers' is adopted from the 2006 World Health Organisation (WHO) definition that states:

Health workers are people whose job it is to protect and improve the health of their communities. Together. these health workers, in all their diversity, make up the global health workforce (WHO: 2006).

Dal Poz et al. (2007: 1-2) highlights the complexities of such a broad and inclusive 'diversity', rightfully drawing attention to the limits that researchers need to apply in their writing about who they intend to focus upon. For the purposes of this paper, the concept medical workers remains limited to doctors and support workers who are graduates from auxiliary services such as pharmacy, physiotherapy, audiology, speech therapy and optometry, among other related services. The target group is limited to 40 medical personnel from the University of KwaZulu-Natal and medical facilities linked to it, whose ages ranged from 26 to 35 years in 2017-2018. A drawback to this paper could well be the criticism that the voices of African doctors do not appear here, which I accept. But they were not my focus of attention for this paper because my preference was to remain focused mainly on Indians. Purposive sampling was therefore the most practical approach to this qualitative study, accompanied by the snowballing technique that introduced me to others who were known to those who were initially willing contacts. An arbitrary cut-off point of 40 interviews were carried out - 20 done personally on a face-to-face basis and 20 were administered through questionnaires through the assistance of 3 colleagues (lecturers) from the KwaZulu-Natal University Medical School. Care was taken to try and ensure that there was a gender balance between males and females in both the personal interviews and the distributed questionnaires both of which elicited openended responses. But advantage was taken over who was most available with their time for interviews. Thirty of the responses 
were from doctors, and two each from speech therapists, audiologists, optometrists, pharmacists and physiotherapists. Among these workers, migration is a widely talked about topic and remains an option to many. The factors that instigate such a thought are entrenched in endemic socio-political problems that are interwoven into a complex web of national and international relations.

This article therefore adopts a somewhat pessimistic position that there are no easy answers, especially since the present conditions appear to be more asphyxiating than promising (John 2014; Donnelly 2015). National role players in the post-apartheid state have moved from providing critical perspectives on the effects of apartheid policy on health delivery (Price 1986; Ncayiyana 2011; 2012; Digby 2013) to providing critical perspectives on the management of health issues by the post-apartheid state (Kon \& Luckan 2008; Coovadia 2009; van Rensberg \& Benatar 2012). While there is recognition that the introduction of primary health has reached and served segments of the population that were ignored in the past, the failures that still abound are inexcusable. Closely following this shift is the critical inquiries into the migration of doctors and the structural conditions that encourage such decisions (Van Rooyen 2000; Arnold 2000; Bezuidenhout et al. 2009; DonWanchope 2010). Shaped around the constructs of the lived experiences of doctors, nurses, and relational services such as audiology, speech therapy, dentistry, physiotherapy and optometry, there is growing interest in the nexus between migration and service delivery, as well as how this nexus is a reflection of state-induced constraints and limitations. At least three issues have been identified among numerous others that can be listed here as deteriorating factors: visionless political leadership; stagnating educational standards; and a lack of confidence in what the future has to offer them (Argus 2005; Manish 2005; Cassim 2013; Rondganager 2013; John 2014; Donnelly 2015). By virtue of their statuses as qualified medical workers and saviours of life, medical personnel's demand for higher standards in social, educational, political and working conditions places them in more privileged positions of exercising their options of mobility from state to private health care, from under-resourced state facilities to better ones anywhere in the country, and from one country to another.

\section{Contextualising the Problem}

It is an accepted fact that knowledge workers with qualifications of a universal 


\section{Anand Singh}

appeal have the privilege of being more mobile than their ordinary counterparts. Among medical workers, their costly training and value to the health of the world provide them with a flexibility of being internationally mobile in ways that only a handful of other professions may allow. As severe reductions in state spending on social services became a norm over the last two decades, even the wealthiest countries began producing fewer health workers. Their health workers requirements, therefore shifted from producing their own to recruitment from developing countries as the three sub sections below reveal.

\section{International Perspectives on Medical Workers}

While major English speaking countries such as the United States, Canada, United Kingdom, Australia and New Zealand have been branded as major 'culprits' in medical worker poaching, emerging Middle Eastern economies too are rapidly becoming destinations for physicians, nurses and auxiliary health workers. In 2006 the World Health Organisation (WHO) estimated that there was a shortage of at least 4.3 million health workers across the world. Since developed countries have become the major beneficiaries in the migration of health workers, debates around the individual health workers right to leave and the ongoing capitalisation upon developing countries' losses have led to widespread polarisation (OECD 2010; IOM 2018). Subsequent conferences in Toyako (Hokkaido, Japan) in 2008 and in L'Aquila (Italy) in 2009 have affirmed the earlier fivefold needs to manage the problem: increase training capacity, improve retention and management of the health workforce, address health worker concerns, monitoring of the flows, and develop an international code of practice in recruitment processes (OECD: 2010: 1). Eight years later, the International Organisation on Migration (IOM) (2018) reported that the migration of health workers remains on the rise, and the problem is likely to escalate. In a recent comparative study on four 'sending' countries, Jamaica, India, the Philippines and South Africa, Walton-Roberts et al. (2017) have produced a paper on Human Resources for Health in India. Health workers in India is one of the country's major exports globally, and are likely to be among the major contributors to the remittances that has now made India the biggest recipient of this category of foreign funds. Against the background of better services being provided in areas away from remote rural enclaves, they found that skilled health worker shortages from India is not simply a 
gravitation towards developed countries through migration alone. Issues such as domestic policies on training, recruitment and retention, must be examined in relation to migration. While the state funded public hospitals are meant to serve India's indigent masses, private health care is presently playing a significant role in health service delivery, including the training of health workers. The shift from state provided health care to private health is astounding: 60 percent of the hospitals and 75 percent of the dispensaries are, at this historical juncture, privately owned; and 80 percent of all doctors in India are now privately employed (Walton-Roberts et al. 2017). Up to 50 percent of the newly qualified health workers in India are inclined to migrate overseas. It is important to note here that between 1947 when India first got its independence, and 1991 when India first opened up its economy to free market conditions, the health sector was almost entirely state driven.

\section{Medical Worker Migration from Sub-Saharan Africa}

Eastwood et al. (2005: 1893) have argued that although some other countries such as Nepal, Bhutan, Papua New Guinea, Afghanistan, Cambodia, and Indonesia seriously lack doctors the problem is especially severe in subSaharan Africa. Since World War Two evidence shows that although many of these countries have made considerable efforts to train their own doctors, the rate of loss of migration often outstrips their production. International perspectives on physicians and medical personnel in Sub-Saharan Africa reveal an ongoing loss of medical personnel to the developed states, particularly to the United Kingdom, USA, Canada, Australia and New Zealand. Eastwood et al. (2005) make a disconcerting revelation about sub-Saharan Africa that 24 of the 47 countries have only one medical school each while 11 have no medical school at all. The Ghana Ministry of Health estimated that $60 \%$ of the country's doctors that trained in the 1980s have actually left the country. An astounding figure of 200 doctors left in 2002 alone (see also Eliason et al. 2014). In 2003, UK work permits were approved for 5880 health and medical personnel from South Africa, 2825 from Zimbabwe (see also SAMP n.d; Chibango 2013), 1510 from Nigeria (see also Otubu 2008), and 850 from Ghana, despite these countries being included among those proscribed for NHS recruitment. Hagopian et al. (2004) assert that the migration of over 5000 doctors from sub-Saharan Africa to the USA has had a significantly negative effect on the doctor-to-population ratio of Africa. Since 


\section{Anand Singh}

World War Two the American physician workforce has had significant numbers added to it through foreign-trained international medical graduates (IMGs). The mobility of the IMGs from home to host country was conditional upon their acceptance of being posted to areas underserved by locally trained physicians because of their remote locations. Hagopian et al. (2004:np) argue that immigration theory identified 'push factors' as instigators in professional mobility from poor countries in favor of settling in higher income countries. The push factors include 'insufficient suitable employment, lower pay, unsatisfactory working conditions, poor infrastructure and technology, lower social status and recognition, and repressive governments'. In the wealthier countries the 'pull factors' were identified as including training opportunities, higher living standards, better practice conditions and more sophisticated research conditions. In the cited works above by writers on Ghana, Zimbabwe and Nigeria, the reasons given by medical personnel themselves to researchers were all too familiar as characteristic of contemporary conditions in Africa.

It is against the background of these structurally induced conditions, that the international macro-mobilities (international migration) and local micro-mobilities (inter-provincial migration) of the medical personnel need to be understood. Initial probationary stints of up to two years in generally remote unpopular destinations, are the conditionalities that foregrounds their international migration. Viewed through the long term individual and familial purposes and goals, it is the lived and subjective experiences back home that first need to be understood as instigators to the notion of macro-mobilities. Beaton's et al. figures (1975) for 1925 to 1972, necessitates an historical view of migration. They maintain that during apartheid medical workers in South Africa remaining behind to work after graduating was an expression of faith in the country. That level of commitment cannot be taken for granted, as East-wood's et al. (2005) plea illustrates - that the state improve working conditions for medical personnel so that they may remain behind. This thrusts forth two fundamental questions about the sustainability of the health services in the future: How can the inequities of the past in the training of doctors be adequately addressed to meet future requirements? And is the government serious about addressing the growing shortage of medical personnel?

\section{South Africa: Contemporary Issues}

Appreciating contemporary issues in health management and its contribution 
towards doctors wanting to leave South Africa requires a three-pronged approach that tests for consistency in information in the triad that includes the popular media, academic critiques and qualitative responses from medical workers themselves. In each of these areas, evidence points towards a need for more rigorous analysis of administrative responsibilities of a state department that is responsible for the health of the country's population. Recent literature on the mobility of medical workers and other highly trained graduates from South Africa to other countries have provided varying insights to understand this as a part of the growing brain-drain phenomenon. While van Rooyen (2000), Don-Wanchope (2010) and Arnold (2011) for instance provide an almost grudging analysis that renders it implicitly axiomatic as a post-apartheid manifestation, Bezuidenhout et al. (2009) acknowledge medical workers' mobility as an 'old' issue that should stretch beyond the borders of South Africa to incorporate the whole of Sub-Saharan Africa.

Van Rooyen (2000), Don-Wanchope (2010) and Arnold (2011) restrict their analyses of doctors leaving South Africa to push factors such as the increased levels of violence since the April 1994 first general democratic election, deteriorating work and educational environments and reduced opportunities for personal upward mobility, vitiated by inappropriate salary scales and condescending attitudes by the state towards the medical profession.

On the contrary Bezuidenhout et al. (2009) place emphasis on both push and pull factors being responsible for doctors' relocation to developed countries, but with a broader recognition of this as a phenomenon of SubSaharan Africa, and not as a unique manifestation of transformational politics in post-apartheid South Africa. The pull factors in developed countries lay especially in the relatively stable work, economic, social and political environments that they have to offer, with opportunities for personal upward mobility and safe familial lifestyles. However implicit the ideological positions taken in each of the discourses cited above, their presentations are supported in the very clinical analyses by Strachan et al. (2011) titled as: More Doctors and Dentists are Needed in South Africa. Their statistics reveal that South Africa's doctor and dentist ratio per thousand people is generally lower than what is prescribed by the World Health Organisation (WHO). This was not always the situation in South Africa, although the concentration of health care facilities and personnel was for most of the twentieth century racially skewed in favour of Whites. Beaton's et al. (1975) much earlier research in the early 1970 s that set out to investigate the migration of the University of the 
Witwatersrand (Wits) medical school alumni who graduated between 1925 and 1972 , found that $83.6 \%$ of those graduates had remained to practise medicine in South Africa. By 1998 however, in a follow-up investigation into the whereabouts of the Wits medical school graduates, their comparison found that approximately $45 \%$ of physicians who graduated since 1975 were located abroad - mainly in the USA, Canada and Commonwealth countries such as Australia, New Zealand and the United Kingdom. It is especially in these English-speaking countries that South African medical workers tend to gravitate. In a study in Australia, Oberoi and Lin (2006) found in 10 interviews with doctors who left South Africa that it was the push factors that played a greater role than the pull factors in instigating medical workers urge to relocate to other countries. They included what has become well known reasons by now, such as poor remuneration and wages, lack of job satisfaction, lack of future prospects (further education and career development), poor working conditions, HIV/AIDS, poor quality of life, high levels of crime and violence, civil conflict and political instability, and a decline in the quality of the school education system (cited in Bezuidenhout et al. 2009: 212).

\section{The Media}

It is the South African media's constant coverage of health care delivery in South Africa that prompted the research for this project. Media coverage in the KwaZulu-Natal province has resonance in most other daily and weekend newspapers in other provinces of South Africa. But for purposes of this article, I restrict myself to the media available in the city of Durban. In the space of the first three months in 2016, the province's major referral Albert Luthuli Hospital made headlines in Durban's Daily News about faulty equipment, corruption in the purchase of equipment, and incompetence of both staff and management in patient care and management. As I first sat to write a draft of this section of the article over the weekend starting Friday $15^{\text {th }}$ April 2016 to Sunday $17^{\text {th }}$ April 2016, at least 3 cases of deaths in 2 major hospitals were reported in KwaZulu-Natal's most circulated Sunday newspaper, The Sunday Tribune. This obviated the need to collate previous articles that have demonstrated issues around questionable ethics in management and patient care. In the main section of the Sunday Tribune, the lead article on the front page was captioned in bold writing: 'THEY DID NOTHING: Parents demand answers in hospital death'. This was about the death of a three-year 
old in one of KwaZulu-Natal's largest medical centres, The RK Khan Hospital. The child had apparently fallen from the bed but was not attended to while she lay on the floor, despite profuse bleeding from her face and head - to which she later succumbed.

On page 3 of the same main section another striking article about another death at Albert Luthuli Central Hospital, with a caption: 'INFECTION AT HOSPITAL: MORE STEP FORWARD'. The article was about an alleged outbreak of a multidrug-resistant bacterial infection Acinetobacter, which is believed to have claimed the lives of two babies and infected seven others. Acinetobacter is known to cause septicaemia, meningitis, and hospital acquired pneumonia, especially in people with low resistance immune systems. A young woman (White), questioning the treatment of her brother in the hospital after he died of a combination of pneumonia, bacterial meningitis and a throat infection (all symptoms of Acinetobacter), made a public claim: '...I was so happy to know that my brother was going to be treated in the hospital because it is considered one of the top hospitals in the country. After what happened to him, I have a different viewpoint'.

In another section of the same edition of the Sunday Tribune, the Tribune Herald ${ }^{1}$, the front page lead article was captioned as: 'EXPERTS CONFIRM HOSPITAL BOTCH-UP'. Once again, it was about the RK Khan hospital, where it was alleged that medical staff mistook a young pregnant woman's breathing problems for labour, which led to her death. The family lawyer, acting on behalf of the late woman, claimed that based on prima facie evidence, there was enough to demonstrate medical negligence, for which the family was going to sue the Department of Health.

Each of these instances has served to feed into public perceptions of apathy in state provisioned health care. In the absence of private medical insurance the greater segment of South Africa's population is forcibly subjected to state clinics and hospitals, a point that is often unhappily made by people without an alternative. But these issues also connected to the reasons that so many young doctors have given for their urge to want to work overseas.

${ }^{1}$ The Tribune Herald is distributed with the main section and other parts of the Tribune only in Indian dominated residential areas, since it is meant to serve the 'ethnic needs' of Indians. 


\section{The Respondents}

Among the forty respondents, 20 were face to face interviews and the remaining 20 based on questionnaires administered with the help of a senior colleague at the University of KwaZulu-Natal Medical School. Every one of the forty was unhappy with the state of health care in South Africa, but only six had no intention to migrate. Three statements by potential migrant doctors contextualize the conditions that form the basis for their urge to migrate. A 27year old male intern (Indian) who had to first complete a Bachelor of Science Degree before being accepted into medical school lamented that despite being a straight A student every application for entry into medical school in Durban failed. He had to first complete a BSc, which he passed cum laude, and await acceptance into medical school as 'a mature student'.

Now that I am here, Ifeel both triumphant and despondent at the same time...triumphant because my parents wanted me to study medicine because they knew that's what I wanted to do. But I despair every day because there are always budgetary problems in almost everything we need to run this place like a proper hospital. I want to go and work overseas in a situation where we are not treated like whatever we are given to work with is a favour by management. We are treating 99 per cent African patients here, but when we ask for what is needed to work with we are treated like 'Indians wanting too much' convenience to work with .... I just want to go and work in another country where there are no such problems (see also van Rooyen 2000; Westwood \& Phizacklea 2000) $)^{2}$.

A 38 year old woman doctor (White) studying towards a post-graduate specialization cried out that she is working under a registrar who was hardly capable of writing a patient's report. He was allegedly less qualified than she was. Yet every time she applied for a registrar's post she was turend down. She alleged that the shortage of working material extended to even the lack of the most basic hygiene material such as paper towels, which she was forced to

${ }^{2}$ While van Rooyen provides a contextual basis for exodus of Whites from South Africa, Westwood and Phizacklea provide a more international perspective across continents. 
purchase on her own, and therefore refused to share with her colleagues. Her frustration is best revealed in her own words:

Can you imagine, our medical supplies are forever being delayed. We not only don't have swabs and adequate medications to dispense to the patients but we also have to now give people reduced amounts of anaesthetics to make sure it carries us through before the next supply comes in... and that too after quite a fight...My niece who is doing her community service in a Johannesburg hospital mentioned three deaths there over the last few weeks - all because 'affirmative action' doctors gave over-dosed kanamycin injections to TB patients...but you know these things can't be made public ... and the attitude of the nurses is sad ... I've noticed it gets worse when they are talking to Indians and Whites. Even after several of us complained to the hospital manager and the Super-intendant it didn't make any difference .... God .... I am sure I will move to either Dubai or Saudi Arabia once my husband can find a job for himself there. We won't be alone because several of our friends and colleagues are already there... and my niece who is working in Johannesburg wants to go to Canada, because her mother has a friend there ... who said she only sees three to five patients a day before lunch ... and the afternoons are for her to write up her reports ... it's a stress free environment ... over here she sees up to 25 patients a day.

A third respondent (White) succinctly crystalized the problems as he saw it:

There is a: lack of people who care; a lack of competent managers; and a serious lack of proper resources to work with. I love this country, but I will go to work overseas if a registrar position is not made available within the next five years. If I go overseas to work I would want to return, but only if conditions improve here.

Beyond these three conversations, doctors and nurses in state hospitals identified eight issues that are of contemporary relevance to the list of problems that they encounter on a daily basis: huge patient turnouts, insufficient doctors and nurses to help cope with huge patient numbers, dysfunctional or lack of equipment, having to educate patients to first attend the primary care district 


\section{Anand Singh}

clinics before seeking help at the bigger hospitals, the lack of basics such as soaps, paper towels, anesthetics and injections, a pervasive lack of commitment by staff to their work, shrinking opportunities for professional advancement and rampant corruption at higher level that impacts upon resource availability. The last statement is an indication of the wider levels of dissatisfaction against the state's agenda to promote young African doctors to Registrar posts and to higher specialization studies ahead of better performing Indian and White graduates. Each time the issue was spoken about during conversations, spontaneous feelings of despair, constriction and anger arose. While there was general agreement that inequities of the past must be addressed, there was unanimous belief that the state was more inclined towards acting in the interests of political patronage than practical requirements for a competent and sustainable health system. Indian and White respondents accepted the need for transformation and to admit more Africans into the medical fraternity to address inequities of the past. Their concerns, however revolved around two issues. The first is about deteriorating educational facilities in African (and to a lesser extent in Indian areas), which underprepares African students for admission into medical schools. And the second is about the affirmative action appointments (Africans) into positions of authority and specialist studies, often ignoring talent and capability among Indians and Whites. In expressing their frustrations with affirmative action, they tended to blame the state for exercising selectivity and gerrymandering in a situation where the shortage of general practitioners and medical specialists required greater investment for more doctors and specialists.

\section{Professional Critiques}

The problems in state hospitals extend beyond the discontent of doctors and public perceptions of state funded health care institutions. At least three recent assessments show consistency with the comments by doctors who were quoted above. While recognizing the positives in the transformational agenda set out by the state, especially in its dismantling of the historically detested ethnically and racially segregated systems of health care, and replacing it by an integrated comprehensive national service. Coovadia et al. (2009) argued that these failures still persist in weak management, leadership and stewardship. The result is that there is inadequate implementation of what they considered to be often good policies. As the responses above indicated, they too observed that 
crucial aspects of primary health care are not in place and are exacerbated by a crisis in appropriate human resources. Their critique was supported three years later by a medical insurance company, PROFMED (2012) that especially serves the needs of medical graduates. PROFMED brought to attention that

... a report of public health facilities conducted in 2011 that was presented to Parliament, revealed that $74 \%$ of state health facilities failed to comply with cleanliness rules, staff attitude was found to be sub-standard in $69 \%$ of facilities and $55 \%$ did not have the necessary medicines and supplies...Currently all state hospitals fall under the remit of the Department of Public Works (DPW), whilst the running of the facilities is done by the Department of Health (DOH). This creates huge challenges for those who are put in charge of running the hospital. If a boiler blows up, or repairs need to be done to any equipment, other than medical equipment then the manager cannot phone the supplier directly, as he has to contact the DPW first.

Both Coovadia et al. (2009) and PROFMED's (2012) critiques were taken further by Edmeston and Francis's (2013) assessment that South African hospitals have become by default the foundation of the country's health system. Edmeston and Francis argue that undue pressure on hospitals is largely a result of the neglected state of the primary health care system and clinic services nationally. A lack of a proper education initiative by the state has led to a growing lack of public trust in these lower tiers of the health system ${ }^{3}$. The postapartheid approach of a three-tier system in health care, with primary health care provided in clinics, secondary care provided in feeder hospitals and tertiary care in specialist hospitals is, as Coovadia et al. emphasized, a creative approach to state funded provision of health care. But because they are under resourced they remain largely dysfunctional. Local populations are not sufficeently conscientized about the values of primary health care facilities, and with the lack of appropriate resources their popularity stunted before they could even begin to consolidate. Undue pressure on feeder hospitals remains

${ }^{3}$ In an interview with a senior surgeon working in a teaching hospital he pointed out that primary health care (PHC) facilities has grown phenomenally in South Africa. While his view is supported by research on the subject, there is still a lot to be done in the PHC. 


\section{Anand Singh}

normative with an enormity in responsibility over both in-patients and out patients.

Management of health care in post-apartheid South Africa has seemingly missed out on understanding the non-scientific fundamentals of administrative efficiency, especially, as Edmeston and Francis (2013) had identified: managerial efficiency and competency, strong leadership, a culture of good governance and accountability. Respondents to this research initiative no longer believe that the state appointed bureaucrats are serious about the issues that Edmeston and Francis (2013) documented. As health care professionals they are in agreement that the problems in management are with people who are inappropriately qualified or experienced, most of who are beneficiaries of affirmative action policies. Their exhaustion with the contemporary realities in health facilities lay with a range of problems that include absenteeism, arrogance, unwillingness to take requisite instructions, and the desperate need to get personnel to act with the expected level of social responsibility. It is the cumulative impact of these factors that are nudging them away from continued service to the medical profession in South Africa. Edmeston and Francis (2013) make a pointed remark about the problem of personnel, which is best stated in their own words:

With respect to this current reality, the well-documented 'management' problems facing the country's public hospitals should be of immediate concern if we are serious about 'health for all'. This fact is not lost on the media or government, as the need for better management is not an under-reported problem. Government is open in admitting to the current state of crisis and the need for better management, whilst the media is never free of reports on the poor state of public hospitals and the management failures. The question that never seems to be asked though is: what is the nature of these management problems? It seems that there are two issues which simultaneously need to be dealt with in this respect. The first, and most widely reported and discussed, relates to management problems at the level of personnel. Undoubtedly, this side of the story garners the most attention as it is the most well-known.

The problems in health care go beyond the situation in hospitals and clinics and extend towards the auxiliary services as well. Sithole (2013) for instance 
points out that South Africa has a serious burden of eye diseases and unwarranted causes of visual impairment and blindness. The policy documents and guidelines obtained on ophthalmic care had no specific reference to eye health promotion. Her investigations revealed that only $11(23 \%)$ of the managers in provincial health directorates reported that they have integrated vision screening in their health promotion programmes as part of eye health promotion strategies. The Northern Cape Province had no eye care manager and consequently no eye health promotion programmes. Most surprising of all provinces was the Western Cape, widely touted as the 'best run' province in the country because it is not ANC controlled. Sithole found that the Western Cape does not have eye health promotion programmes and relies mostly on the private sector for eye care services, which are often beyond the affordability of the indigent. Against the extensiveness of avoidable eye problems in South Arica, the need for dedicated directorates in all of the provinces that can lead and sustain an integrated eye-health promotion must occur within the framework of a primary health care model. While Sithole's suggestions remain constructive and implies a continued will to work in South Africa, others in the medical auxiliary services remonstrated differently. Their reactions were akin to a protest against the perceived lack of direction by the state in health delivery models, and the situation in the country's realpolitik. In a group interview with new graduates in speech therapy, audiology, occupational therapy and dental therapy, seven ${ }^{4}$ of them expressed the desire to either work overseas for the sake of experience or to want to relocate permanently. Their reasons were almost unanimous: South Africa's high crime levels, perceived better working conditions overseas, and the need to acquire more internationally recognised work experience and qualifications.

\section{The Urge to Fly}

In an interview with a specialist doctor (Indian) a case in point was referred to with jest, but somewhat captured the mood among people who are critical about state funded hospitals and cannot afford private health insurance:

\section{You know a patient I treated in Shifa hospital ${ }^{5}$ for four days recently}

${ }^{4}$ In terms of racial backgrounds, 3 were White, 3 Indian and one African.

${ }^{5}$ An expensive private hospital in Durban that does not treat people without the means to pay for their attention i.e. medical insurance or cash. 
had to be transferred to a state hospital because her medical aid would not cover her treatment. When she was told that she had to be taken to Addington Hospital because her medical aid wasn't enough to cover her care in Shifa, she called her sister and said: 'Please get my lawyer to review my will. This is the end of me'. These are the unfortunate perceptions that the public has of the state institutions, they are just so negative ... although they are not always that bad. State hospitals, when they are properly staffed and equipped offer a tremendous service. But that's where the problem lies, and that's what's causing the younger generation to lose faith and find greener pastures elsewhere. Their urge to fly away from this mess has never been stronger.

The respective doctor made the statement in relation to the question about health care provision in South Africa and already established reasons about why so many would like to leave the country to work elsewhere in the world. But the reasons for wanting to emigrate for work among South Africa's medical personnel are more varied than the issues raised above. Among the forty respondents, the 34 who expressed a desire to work overseas could be broadly categorised into 3 groups: those wanting to leave permanently, those wanting to work for a few years and then decide whether to return or to acquire citizenship in another country, and those wanting to leave but felt constrained by family obligations. While 40 doctors are a comparatively small sample against the broader figure of 27432 (recorded by ECONEX ${ }^{6}$ in October 2010, 17802 general practitioners and 9630 specialists), they do indicate a prevalent trend against two significant issues: general dissatisfaction with the health care management in the country and a widespread tendency to want to migrate in search of perceived better working conditions and congenial safer neighborhoods.

${ }^{6}$ ECONEX: Available at:

https://www.mm3admin.co.za/documents/docmanager/f447b607-3c8f-4eb78da4-11bca747079f/00029035.pdf. They claimed that contrary to officially quoted sources that state that there are 36,912 doctors practising in South Africa, evidence showed in 2010 that there were only 27,432 doctors practising in total (17,802 general practitioners (GPs) and 9,630 specialists). 
In four instances, including three with women and one male, the responses were specific to both households and the country's politics. In an instance with a 52-year old anesthetist, her personal domestic circumstances enabled her to become more mobile after her responsibilities with her two nieces, whose parents died tragically in 1994, were deemed 'over'. She chose not to marry out of a sense of commitment to her late sister, whose children she felt obliged to raise after their parents died in an accident. She lived with her mother and two nieces and bore full responsibility towards their expenses. After both her nieces graduated and sought gainful employment she chose to apply for work in Dubai. But her reasons were more than just her domestic circumstances. She felt that working in Dubai where stringent laws against criminals gave ordinary working people peace of mind during weekends when they choose to socialise away from their homes. The endemic crime in Souith Africa did allow them such a privilege.

An Intensive Care Unit (ICU) 50 year old nurse who has worked in Saudi Arabia for nine years returned to visit her son in Durban early April 2016. She returns home every 18 to 24 months because she knows that he is safe by virtue of living in an apartment block that is known for its generally friendly and cooperative residents. As a single parent with only one child in a friendly environment, she felt enabled to seek work in Saudi Arabia and send back money to her son to meet his living and tuition expenses. There were two factors that prompted her to leave South Africa. Her first was the fright that she got when two of her ICU colleagues died as a result of HIV/AIDS. One apparently contracted the virus in the ward and the other, allegedly through her husband. The apparent sight of HIV patients dying on a regular basis prompted her to seek work in Saudi Arabia, 'because of the tax incentives, a different type of patient population and a crime free country. Seeing AIDS patients wither away in short spaces of time after they come to hospital is just too mentally taxing. I just couldn't take it here anymore'. As a foreign woman in Saudi Arabia she has found it difficult to move about freely, although moving about with friends lessened the anxiety of being seen as a lone woman. Since working as a migrant nurse she was able to save substantially more money, furnish her apartment with more aesthetically pleasing furniture and buy a car for her son. She felt that none of these accomplishments would have been achievable if she remained in South Africa.

In both instances above the women were mature over 50-year old adults whose work overseas was for both personal fulfillment as well as trying 


\section{Anand Singh}

to secure their families financial circumstances in better paid work. While one was a mother and the other not, they both cast protective motherly roles over their families' welfare. Their concerns too revolved around common factors that were characteristic of post-apartheid manifestations: high crime rates and the dangers of treating HIV/AIDS patients in hospitals. While these concerns are often popularly associated with Africans, they were careful not to racialise their responses, conceding that these were not restricted to any race group.

In the other two instances, newly graduated doctors (Indian male and female) who qualified in Romania failed to get acceptance into the South African medical fraternity. Their grouses were at least five-fold:

- They were refused entry into South African medical schools despite having requisite passes after completing Grade 12;

- They had to successfully write examinations to practice in South Africa, despite two anomalies: their Romanian degrees had European Union acceptance but was not acceptable in South Africa; yet Cuban doctors who could barely speak either English or any other South African ethnic language had easy acceptance into South Africa, adding to the range of humiliating experiences.

- They had up to three chances to write and pass their examinations. But on each occasion that they failed they were not told how or why they failed, and were not granted access to their scripts.

- They were neither encouraged to participate in ward rounds with other South African interns and Community Service graduates, nor were they made to feel welcome.

- They were not allowed to be tutored by medical teaching staff in order to prepare for the examinations.

The parents of both graduates believed that the results were intended to frustrate and fail them, and that their results were racialised decisions: 'Our children are failing because they are Indian. I would like to put my daughter side by side with one of the African doctors who just graduated from UKZN and let's see how much they know!' - cried one father out of frustration ${ }^{7}$. He was loathe to send his daughter to work in Europe because she was his

7 This statement must be strictly seen as a direct reported one, not as judgmental. 
youngest child, and his older two children were married and living away from his home. One left for New Zealand soon after she married, and his son worked in Johannesburg. By the third attempt his daughter passed, providing an indescribable sense of relief because she could now practice in Durban. But her colleague, a doctor's son, had failed his third attempt, so he had to leave for Dublin, Ireland, where he could work unhindered and with years of experience he could possibly return to South Africa, 'hopefully with a Royal College of Surgeons certificate'. The young doctor's parents, the father a pediatrician and the mother a housewife, were equally anxious about not wanting their son to leave home because they had recently lost a married son (also a doctor) in an accident. But their choices were limited and had to let him go '...to avoid further humiliation. We are losing our son to another country, but at least he won't have to work in this messed up health system of ours. I know this is like sour grapes, but we are forced to see this as our consolation. What choice do we have?'

In the two case studies above both were below the age of 30 years and only just starting off their careers. Unlike the two motherly figures above, their experiences were bitterly couched in racialised tones. A significant number of South Africans who study abroad are Indians of middle-class background who have been denied spaces in the country's medical faculties. Their return from overseas forces them to feel alienated because they have to write qualifying examinations even though studying medicine in Ireland and Romania have European recognition. The comparison that the parent made about her child and African qualified doctors abounds in the private social spaces of Indians and Whites, as well as in the media, albeit in not so direct terms. These are statements borne more out of frustration with the state's treatment of their children than about a real want to view their experiences in racialised ways.

\section{Conclusion}

It is clear from the responses by the popular media, academic critiques and medical personnel themselves that the post-apartheid state is not meeting the demands that health care requirements imposes upon them. The state's failure to employ doctors and nurses in the positions that remain unfilled is creating enormous pressure on those who are serving in government hospitals and clinics. Having to attend to large numbers of patients per day without adequate facilities is antithetical to congenial working environments; and having to 


\section{Anand Singh}

contend with bureaucrats who lack the sensitivity for adequate provisions in medical facilities for their proper functioning raises crucial questions about contemporary and future conditions in which to work. Medical personnel's problems are exacerbated when appropriate equipment is either unavailable or not functional, and when conditions in hospitals lack the requisite levels of cleanliness to work in. PROFMED's report about 74 percent of state hospitals not meeting the cleanliness tests must reflect negatively upon those who are appointed to manage the health institutions. When individuals with positive track records in their commendable stand against apartheid, such as Coovadia (2009) and Edmeston and Francis (2013) openly raise concern about incessant problems in health care delivery, then those with a knowledge of South Africa's late twentieth century political history will understand the authenticity of their critiques.

KwaZulu-Natal, like most other provinces in South Africa, has English as the medium of communication in most state institutions. But when the state chooses to employ Cuban doctors who are hardly conversant in English over South African Indian graduates with degrees that are EU recognised, cries of racial discrimination against Indians and Whites should be viewed as an expected outcome. Coupled against equity policies that places affirmative action against meritocracy, and not informing medical graduates who qualified outside South Africa about how and why they failed, only adds to perceptions of closet racism by the post-apartheid authorities. Such decisions by the state have the inevitable consequence of alienating doctors who have the potential to positively contribute towards health care in the country. The cumulative impact of these situations in South African hospitals are what is directly responsible for medical personnel weighing their options against perceived better working conditions overseas.

While some potential emigrants intend to permanently relocate, others want to work overseas in the hope of returning to work under improved conditions. The positive responses from such respondents was that they understood and believed in the need to create a balance between equity targets and merit selections for those wanting to study medicine. This is a reasonable position to take against centuries of discrimination against Africans who were denied educational opportunities that Whites and middle-class Indians enjoyed. If conditions improve, the chances are that many who intend to relocate permanently could willingly return to serve the country; but if they deteriorate further, the country is likely to lose more medical personnel, with 
the chances of those wanting to work overseas for a few years and then return, not wanting to return at all. The future quality of health care therefore would depend upon who remains, how they create a balance between meritocracy and affirmative action to select future aspirant doctors for training, and what the state would do to ensure that doctors remain in the country to serve an increasingly anxiety ridden population ${ }^{8}$.

\section{References}

Arnold, P.C. 2011. A Unique Migration: South African Doctors Fleeing to Australia. CreateSapce. United States of America.

Beaton G.R, A.D. Mendelow, D.E. Bourne 1975. A Career Study of Medical Graduates of the University of the Witwatersrand, 1925-1972. South African Medical Journal 40: 2131 - 2139.

Bezuidenhout, M.M., G. Joubert, L.A. Hiemstra \& M.C. Struwig 2009. Reasons for Doctor Migration from South Africa. South African Family Practice 51,51: 211 - 215. Available at:

http://www.google.co.za/url?sa=t\&rct=j\&q=\&esrc=s\&source=web\&cd= 4\&ved=0ahUKEwjd O7hnI7OAhVEF8AKHdHSBbkQFggyMAM\&url =http\%3A\%2F\%2Fwww.safpj.co.za\%2Findex.php\%2Fsafpj\%2Farticle \%2Fdownload\%2F1152\%2F1546\&usg=AFQjCNFx6odDfO7PbciCZO

N6wbESNNX1Sw (Accessed on 24 July 2016.)

https://doi.org/10.1080/20786204.2009.10873850

Cape Argus: 2005. http://sepiamutiny.com/blog/2005/03/18/south_african_p/

Cassim, Z. 2013. Doctors who Cheat the State. Available at:

http://www.corruptionwatch.org.za/doctors-who-cheat-the-state-

surgeon-speaks-out/ (Accessed on 23 April 2016.)

Chibango, C. 2013. Zimbabwe's Medical Brain Drain: Impact Assessment on

Health Service Delivery and Examination of Policy Responses - A Literature Review. European Journal of Sustainable Development 2,4: 43

- 58. (Accessed on 27 July 2016.)

https://doi.org/10.14207/ejsd.2013.v2n2p43

${ }^{8}$ I make this statement against the background of the recent ruling against former President Zuma, who the Constitutional Court found guilty of not acting in the spirit of the constitution by virtue of using tax-payers money for his personal needs. 
Coovadia, H., R. Jewkes, P. Barron, D. Sanders, D. McIntyre 2009. Health in South Africa 1: The Health and Health System of South Africa: Historical Roots of Current Public Health Challenges. Lancet 374: 817 - 34. Available at:

http://www.parliament.gov.za/live/commonrepository/Processed/201203 16/390887_1.pdf (Accessed on 23 March 2016.) https://doi.org/10.1016/S0140-6736(09)60951-X

Cullinan, K. 2015. Exodus of Free State Doctors.

http://www.health-e.org.za/2015/10/21/exodus-of-free-state-doctors/ (Accessed on 23 April 2016.)

Dal Poz, M.R., Y. Kinfu, S. Dräger \& T. Kunjumen 2007. Counting Health Workers: Definitions, Data, Methods and Global Results. Department of Human Resources for Health World Health Organization. Available at: http://www.who.int/hrh/documents/counting_health_workers.pdf (Accessed on 10 August 2018.)

Digby, A. 2013. Black Doctors under South Africa's Apartheid Regime. Medical History (Cambridge Journals). Available at:

http://journals.cambridge.org/action/displayAbstract?fromPage=online \& $\underline{\text { aid }=8869682 \& \text { fileId }=\text { S0025727312001068 }}$

(Accessed on 28 March 2016.) https://doi.org/10.1017/mdh.2012.106

Donnelly, L. 2015. Zuma Appoints Pravin Gordhan as Finance Minister. Mail and Guardian 13 December 2015. Available at:

http://mg.co.za/article/2015-12-13-zuma-appoints-pravin-gordhan-asfinance-minister

(Accessed on 29 July 2016.)

Don-Wanchope, A.C. 2010. State Hospitals, Academic Medicine and the Decline of Health Care in South Africa - A Cry of Support from Those Who have Left for Those Who Stay. South African Medical Journal 100:2 (no page numbers listed). Available at:

http://www.scielo.org.za/scielo.php?script=sci arttext\&pid=S025695742010000200003 (Accessed on 25 July 2016.)

https://doi.org/10.7196/SAMJ.3966

Eastwood, J.B., R.E. Conroy, S. Naicker, P.A. West, R.C. Tutt \& J. PlangeRhule 2005. Loss of Health Professionals from sub-Saharan Africa: The Pivotal Role of the UK. Lancet: 365: 1893 - 900. https://doi.org/10.1016/S0140-6736(05)66623-8 
Edmeston, M. \& F. Kate 2013. Beyond Band Aids: Reflections of Public and Private Health Care in South Africa. Available at:

http://hsf.org.za/resource-centre/focus/focus-

67/MEdmeston_KFrancis.pdf/view

Eliason S., D.A. Tuoyire, C. Awusi-Nti \& A.S. Bockarie 2014. Migration Intentions of Ghanian Medical Students: The Influence of Existing Funding Mechanisms of Medical Education (The Fee Factor). Ghana Medical Journal 48,2: 78 - 84.

http://www.ncbi.nlm.nih.gov/pmc/articles/PMC4310336/

(Accessed on 26 July 2016.)

https://doi.org/10.4314/gmj.v48i2.4

Grobbelaar, R. 2011. Medical Schools' Race Bar. Times Live. Available at: http://www.timeslive.co.za/local/2011/05/19/medical-schools-race-bar Hagopian, A., M.J. Thompson, M. Fordyce, K.E. Johnson, \& L.G. Hart 2004. The Migration of Physicians from sub-Saharan Africa to the United States of America: Measures of the African Brain-Drain. Human Resources for Health 2: 17.

http://www.ncbi.nlm.nih.gov/pmc/articles/PMC544595/ (Accessed on 25 July 2016.)

https://doi.org/10.1186/1478-4491-2-17

Haynes, M.A. \& A.B. Lee 1995. Medunsa and the Training of Black Doctors for South Africa. Pubmed.gov: US National Library of Medicine. Available at:

http://www.ncbi.nlm.nih.gov/pubmed/7865036;

https://doi.org/10.1097/00001888-199502000-00014

International Organisation for Migration (IOM) 2018. World Migration Report: Migration of Health Workers. Available at:

https://www.iom.int/migration-health-workers

Karyn, M. 2005. Parents Dig their Heels into UCT Race Issue. Available at: news/south-africa / http://www.iol.co.za/news/south-africa/parents-digtheir-heels-into-uct-race-issue-235445

(Accessed on 04 March 2005.)

Kon, Z.R. \& N. Luckan 2008. Ethnic Disparities in Access to Health Care in Post-Apartheid South Africa. American Journal of Public Health Care 98,12: 2272- 2277. Available at:

http://www.ncbi.nlm.nih.gov/pmc/articles/PMC2636545/

(Accessed on 29 July 2016.) https://doi.org/10.2105/AJPH.2007.127829 
Manish 2005. Q is for Quotas. Available at: http://sepiamutiny.com/blog/2005/03/18/south_african_p/

Mlandu, L. 2013. South Africa Running out of Specialist Doctors. Available at:

http://ewn.co.za/2013/10/30/HASA-SA-running-out-of-specialistdoctors

Ncayiyana, D. 2011. Medunsa's Rebirth would Do Well to Start with a Truth and Reconciliation Process. South African Medical Journal. (SAMJ First published January 1884.) August, 101, 8. Available at:

http://www.samj.org.za/index.php/samj/article/view/5161/3315

Ncayiyana, D. 2012. WSU Medical School - A Study in Innovation and Resilience. South African Medical Journal (SAMJ: First published January 1884.) February 2012, 102, 2. Available at: http://www.samj.org.za/index.php/samj/article/view/5659/3839

Ndaliso, C. 2014. Cadres behind Exodus of Young Doctors. Available at: http://www.iol.co.za/news/south-africa/kwazulu-natal/cadres-behindexodus-of-young-doctors-1741326; https://doi.org/10.7196/SAMJ.5659

Oberoi, S.S. \& V. Lin 2006. Brain Drain of Doctors from Southern Africa: Brain Gain for Australia. Australian Health Review 30,1: 25 - 33. https://doi.org/10.1071/AH060025

Organisation for Economic Cooperation and Development (OECD) 2010. International Migration of Health Workers: Improving International Cooperation to Address the Global Health Workforce Crisis. Policy Brief. Available at:

http://www.who.int/hrh/resources/oecd-who_policy_brief_en.pdf

Otubu, O. MD 2008. Physician Migration from Nigeria: A Look at the influential factors and Suggested Policy Options. A Master's Paper submitted to the faculty of The University of North Carolina at Chapel Hill. In partial fulfillment of the requirements for the degree of Master of Public Health in the Public Health Leadership Program. Chapel Hill. Available at:

https://www.google.co.za/?gfe $\mathrm{rd}=\mathrm{cr} \& \mathrm{ei}=\mathrm{CFGHV}$

xKYep8weEva2IDg\&gws_rd=ssl\#q=Push+factors\%2C+Doctors\%2C+ Nigeria

(Accessed on 27 July 2016.)

Price, M. 1986. Health Care as an Instrument of Apartheid Policy. Health and Policy Planning: The Journal of Health Policy and Systems Research 1,2: 
158 - 170. Available at:

http://heapol.oxfordjournals.org/content/1/2/158.abstract;

https://doi.org/10.1093/heapol/1.2.158

PROFMED 2012. Crisis in Public Hospitals can be Fixed through Proper Management. Available at:

http://www.profmed.co.za/News-Blog/Blog/Crisis-in-public-hospitals

Rondganger, L. 2013. SA Needs 14351 doctors, 44780 nurses. Daily News 22 January 2013 at $13.30 \mathrm{pm}$. Available at:

http://www.iol.co.za/dailynews/sa-needs-14-351-doctors-44-780-nurses$\underline{1456417}$

SAMP n.d. Medical Leave: The Exodus of Health Professionals from Zimbabwe. Southern African Migration Project, Migration Policy Series No. 34. (Series Editor: Jonathan Crush.)

Sithole, H.L. 2013. A Critical Analysis of the South African Health Policies and Programmes with Regard to Eye Health Promotion. Available at: http://uir.unisa.ac.za/handle/10500/11833.

Strachan, B., T. Zabow \& I.M. van der Spuy 2011. More Doctors and Dentists are Meeded in South Africa. South African Medical Journal 101,8: 523 528. Available at:

http://www.sajhrm.co.za/index.php/sajhrm/article/view/372/382 (Accessed on 25 July 2016.)

The Daily Telegraph 2005. Indian in Court over South African Quota. The Daily Teleraph $5^{\text {th }}$ March 2005. (Accessed on 1 March 2016.)

Van Rooyen, J. 2000. The New Great Trek: The Story of South Africa's White Exodus. Pretoria. UNISA Press. University of South Africa.

Victoria, J. 2014. Matric Pass Rate Highest Yet at 78.2\%. Mail and Guardian 6 January 2014. Available at:

http://mg.co.za/article/2014-01-06-matric-pass-rate-highest-yet-at-782 (Accessed on 29 July 2016.)

Walton-Roberts, M., V. Runels, S. Irudaya Rajan, A. Sood, S. Nair 2017.

Causes, Consequences and Policy Responses to the Migration of Health Workers: Key findings from India. Human Resources for Health.

Available at:

https://human-resources-

health.biomedcentral.com/articles/10.1186/s12960-017-0199-y

(Accessed on 29 August 2018.)

https://doi.org/10.1186/s12960-017-0199-y 


\title{
Anand Singh
}

Westwood, S. \& A. Phizacklea 2000. Transnationalism and the Politics of Belonging. London and New York. Routledge.

World Health Organisation (WHO) 2006. Health Workers. Available at: http://www.who.int/whr/2006/06_chap1_en.pdf

\author{
Anand Singh \\ Anthropology \\ University of KwaZulu-Natal \\ singhan@ukzn.ac.za
}

